\title{
Conservation narratives and conflicts over protected areas in post-socialist Romania
}

\author{
Marie Louise Aastrup ${ }^{1}$ \\ Memorial University of Newfoundland, Canada
}

\begin{abstract}
Environmental protection is never a controversy-free endeavor. Conflicts arise over land ownership, use, and access. Political ecologists have paid extensive attention to protected areas, especially in relation to power, rights, and marginalized peoples. This article draws on political ecology to examine a new proposed national park in the context of post-communism and neoliberalization in Romania. Using mixed-methods (semistructured interviews, questionnaires, and participant observation), this research investigates conservation narratives as articulated by different actors (environmental non-governmental organizations, local decisionmakers, and local community members) with various levels of involvement in the proposed national park. Three chief narratives can be observed pertaining to tourism, restrictions, and deforestation. These narratives are embedded in the history and socio-economic context of the area, but also reveal the agendas of different actors regarding landscape values. Assessing these narratives, this research reveals how actors position themselves and the points of contention among the different actors in the brewing conflict that the national park represents.
\end{abstract}

Keywords: Political ecology, conservation, conflict, power

\section{Résumé}

La protection de l'environnement ne se fait jamais sans controverse. Des conflits surviennent au sujet de la propriété des terres, de leur utilisation et de l'accès à celles-ci. Les écologistes politiques se sont intéressés de près aux aires protégées, particulièrement en relation au pouvoir, aux droits et aux peuples marginalisés. Cet article s'appuie sur l'écologie politique pour examiner un projet de nouveau parc national dans le contexte du postcommunisme et de la néo libéralisation en Roumanie. Par le biais de méthodes mixtes (interviews semistructurées, questionnaires et observation participative), cette recherche analyse les discours sur la protection de l'environnement de différents acteurs (organisations environnementales non-gouvernementales, dirigeants locaux, membres de communautés locales) plus ou moins impliqués dans le projet de parc national. Trois discours principaux peuvent être dégagés, en rapport au tourisme, aux restrictions et à la déforestation. Ces discours s'intègrent dans l'histoire et dans le contexte socio-économique de la région, mais ils révèlent aussi les intentions des différents acteurs quant aux valeurs associées au paysage. En analysant ces discours, cette recherche révèle la position des acteurs ainsi que les points de discorde entre les différents acteurs dans le conflit latent que représente le parc national.

Mots-clés: Écologie politique, protection de l'environnement, conflit, pouvoir

\section{Resumen}

Environmental protection is never a controversy-free endeavor. Conflicts arise over land ownership, use, and
access. Political ecologists have paid extensive attention to protected areas, especially in relation to power,
rights, and marginalized peoples. This article draws on political ecology to examine a new proposed national

${ }^{1}$ Marie Louise Aastrup, PhD student, Department of Geography, Memorial University of Newfoundland, Canada. Email: mlaastrup@mun.ca. Acknowledgements: I would like to thank Dr. Arn Keeling and Dr. Alistair Bath at Memorial University, and Dr. Carly Sponarksi at University of Maine for their supervision. I would also like to thank Dr. Stefan Dorondel at University of Bucharest, Alex Zahara and Simone Cominelli at Memorial University of Newfoundland, and the reviewer for their feedback on drafts. I would like to acknowledge my research assistants Alin Puiu, Luca Maugeri, and Alexandra Iona Mircea as well as Dr. Florin Nechita at Transilvania University of Brasov for their help in the field. I would also like to thank Oak Foundation and Foundation Conservation Carpathia for financially supporting my fieldwork. 


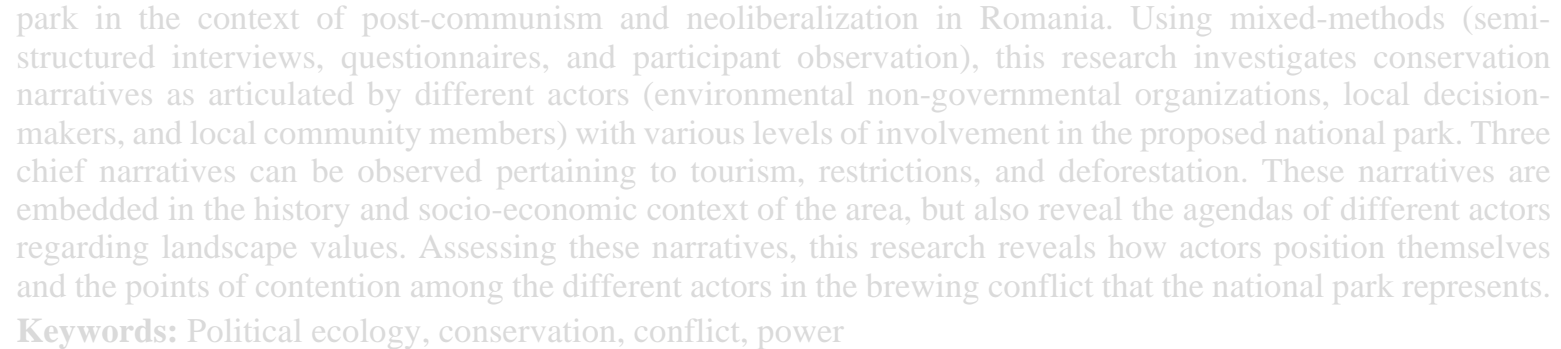

\section{Introduction}

Nature conservation activities are a minefield of potential conflicts over rights, access, environmental and social justice, ways of knowing nature, and management practices (Cortés-Vázquez 2014; Sen and Pattanaik 2017). Conservation practices, protected areas, their situated historical geographies, issues of access, and user rights have been the subject of much political ecology research (Brockington 2004; Kelly 2011; Neumann 2015; Roth 2004; Sodikoff 2009). A political ecology perspective suggests that such conflicts do not occur in a vacuum but should be viewed in light of their historical, political, and social contexts (Bridge et al. 2015; Robbins 2012). The narratives about conservation and environmental protection employed by different actors may reflect different ideologies and political agendas - contradictions which become increasingly clear in the context of contemporary protected area establishment. Conservationists legitimize the establishment of protected areas by drawing attention to the potential benefits that protected areas bring to global publics and may bring to local communities (Bratman et al. 2012; Jones et al. 2017; Sodhi et al. 2010). However, perhaps despite good intentions, protected areas do not always deliver on their social promises, and research on the impact of protected areas on local people is vast (e.g. Holmes and Cavanagh 2016; Jacoby 2001; Pullin et al. 2013; West et al. 2006). The designation of protected areas can disrupt local communities through displacement and loss of access to resources (Brockington 2004; Cundill et al. 2017; Elmhirst 2012; Neumann 2001; Vaccaro et al. 2013). How different actors evaluate protected areas depends on the perceived detriments or benefits they anticipate protected areas will bring (Horowitz 2010). Thus, understanding the conservation narratives different actors employ not only reveals how these actors position themselves in relation to the protected area in question, but also identifies potential conflicts or points of contention.

In this article, I will show how actors use different conservation narratives regarding a new proposed national park in the Făgăraș Mountains in central Romania, and how these contradictory narratives reflect the connections between broader political-economic ideals and land use management in their historical and contemporary contexts. The Romanian communist regime (1947-1989) collectivized the lands surrounding the Făgăraș Mountains. Agricultural lands were collectivized in the Cooperativa Agricolă de Producţie (CAP) and forests were nationalized. Subsequently, with the fall of communism, lands were privatized and in 2007 the Romanian state designated the Făgăraș Mountains a protected area under European Union (EU) law.

The Făgăraș Mountains are largely unpopulated but are surrounded by 25 municipalities, all of which have varying amounts of municipal land in the mountains. With the financial support of international philanthropists, a conservation foundation is working towards establishing a national park in the Făgăraș Mountains. This Romania-based foundation, led by German conservationists, is currently buying up land to establish a national park that will be returned to the public domain, with the foundation as custodian of the area. Due to the nature of various types of landownership, purchasing the entire 200,000 ha is not possible. The foundation owns approximately 10 per cent of the area currently, which is under private protection. Although the Făgăraș Mountains are not yet a national park, the area is an EU Natura 2000 protected area.

Political ecology provides a useful framework for answering the questions that arise in relation to how the Făgăraș Mountains "hybrid" public/neoliberal conservation initiative has come to be. How do different actors (conservationists, local decision-makers, and local community members) envision the future of a landscape that was once nationalized, then privatized, and then designated a protected area in an EU wide 
network? Where lie the contradictions, potential conflict points, and common understandings within these different conservation narratives?

To answer these questions, I used a mixed-methods approach based on qualitative interviews, a questionnaire, document analysis, and participant observation to carry out research in eleven of the communities bordering the proposed park. I analyze the conservation narratives employed by different actors (local decisionmakers, conservationists, and local community members) in order to reveal the (conflicting) landscape visions and agendas that different actors hold and how these narratives manifest across scalar arrangements. These narratives are situated within the historical, political, and ecological context of the Făgăraș Mountains. It is this context of land privatization, changing property rights and environmental policies that make conservation narratives around the Făgăraș Mountains particularly interesting. The conservation narratives do not only reveal actors' positions and power relations (Bixler 2013; Campbell 2007), but also tells a story about rapid societal change and the consequences thereof. I present three chief conservation narratives and show how these reflect the different visions for a transforming landscape, and how they are employed at different levels. These narratives reveal potential points of contention, and how actors situate themselves in the brewing conflict between global conservation ideas and local reactions.

\section{Relevance of political ecology to conservation in Eastern Europe}

Parks and protected areas are always political projects, as they (re)define user and access rights to resources and draw borders (Adams 2017; Neumann 2015; Vaccaro et al. 2013). For example, Byrne and Wolch show how parks "are not ideologically neutral spaces" (2009: 745) with reference to how national parks in the U.S. were spaces of class and racial segregation, and how this ideological foundation is reflected in today's park use (e.g. less visitation to parks by African American and Hispanic Americans). While the literature dealing with conservation initiatives from a political ecology perspective is vast (e.g. Adams 2017; Cortés-Vázquez 2014), political ecologists have primarily paid attention to conservation issues in (post)-colonial conservation in the what is often termed the "Global South" or in Indigenous communities (e.g. Ambinakudige 2011; Brockington 2004; King 2010; Mombeshora and Bel 2009; Neumann 2001; Radel 2012; Roth 2004; Sen and Pattanaik 2017; Sodikoff 2009). Overall, literature dealing with the political ecology of nature conservation in the context of Eastern Europe is sparse (Blavascunas 2014; Kay 2014; Petrova 2014; Staddon 2009; Stahl 2010), especially regarding conservation initiatives in Romania (Bauer et al. 2018; Cotoi 2017; Dorondel 2016; Vasile 2008).

A major component of these environmental laws is the designation of ecologically representative protected areas and species under the Natura 2000 framework (Directive 92/43/ECC and Directive 79/409/ECC). The process of Europeanization (i.e. the process of states adopting to the rules of the EU) conservation policies began, in some instances, prior to accession (Yakusheva 2017). Following accession to the EU, many ECE (East Central European) countries experienced drastic increases in the percentage of land protected as a result of Natura 2000 designations (Iojă et al. 2010; EEA 2012). This illustrates the role of meeting environmental law, and therein also the role of conservation efforts, as a means to a greater political end, namely becoming part of the EU. For new member states, aligning national environmental law to that of the EU is not considered to be a painless endeavor, but rather a "necessary evil" as part of a greater quest to obtain EU membership (Andonova 2005; Yakusheva 2017). This new type of nature protection has been met with strong opposition from local communities, as some Natura 2000 areas have been perceived by locals to be a nuisance, even by those who are generally supportive of conservation initiatives (Pietrzyk-Kaszyńska et al. 2012). This resistance is not only a characteristic of "new" member states, but also exists among members of the public in "old" member states (Keulartz 2009).

\section{The "Yellowstone of Europe"}

The proposed Făgăraș Mountains National Park is an interesting case seen in the light of this historical development of protected areas. At a first glance, it represents a neoliberal conservation initiative, with the buying of land supported by international philanthropists. What makes this case an interesting hybrid is the intention to return the park, once established, to the public domain with a written agreement on the 
(conservation-oriented) management of the area. This intention is a potential variation of neoliberal conservation, although the initiative is still rooted in such an approach (established through philanthropy, initial private ownership, and focus on conversation-oriented livelihood strategies) and employs neoliberal strategies to achieve its conservation vision. What is more, conservationists are promoting this hybrid conservation initiative under the banner of a "Yellowstone of Europe", in reference to the Yellowstone National Park in the United States - the poster child for fortress conservation. So-called "fortress conservation" refers to the way in which early protected areas were established, which, as the name indicates, followed a "fence and fine" strategy of managing natural spaces (Fletcher 2010), with power (typically) exercised by the state through evictions and restricted access (Brockington 2004). This model has been criticized for its command-and-control strategies, for keeping people out, and displacing local resource users (Fletcher 2010; Jacoby 2001).

Neoliberal conservation strategies employ marketization, commodification, privatization, and decentralization to enact conservation initiatives. This type if conservation has become increasingly prevalent (Adams 2017; Holmes and Cavanagh 2016; Langholz and Lassoie 2001; Vaccaro et al. 2013). Commodification of nature refers to the institutional or legal redefinition of elements as marketable products such as ecosystem services, endemic species for pharmaceutical development (bioprospecting), ecotourism, and how these elements have entered the market and can be obtained through monetary payments (Fletcher 2010; Holmes and Cavanagh 2016; Kelly 2011; Sodikoff 2009). While protected areas following a fortress conservation model have been detrimental to local livelihood strategies, neoliberal conservation takes a different approach. It focuses on market-oriented livelihood strategies (e.g. ecotourism) and does so by providing incentives and advocacy for engaging in these (Holmes and Cavanagh 2016). Within neoliberal conservation, the ties between private sector entities and protected areas have increased (Hoffmann 2009). This may benefit local people if they can exploit these ties and connections (Haenn et al. 2014; Igoe and Brockington 2007; West et al. 2006). While on one hand connections to the private sector can provide an outlet for local voices, neoliberal conservation risks increasing the influence of national and international private sector players on local resource uses (Fletcher 2010). In the case of Romania, the (inter)national private sector is already indirectly influential in forest related issues, as logging is often carried out and/or processed by foreign interests.

Neoliberal conservation adds another layer to the ways in which protected areas may affect local people, as market-driven conservation depends on marketing, essentially through (certain) representations of nature and spectacle (Holmes and Cavanaugh 2016). These representations serve the purpose of selling a commodity (not only goods and services, but also experiences) to potential tourists, which can ultimately also reshape the social landscapes they portray (Holmes and Cavanaugh 2016; Kelly 2011). Related to tourism, Holmes and Cavanaugh (2016) highlight the quest for "authenticity" - a commodity sought by the post-modern tourist (Iorio and Corsale 2010) - and how certain groups can become "iconic" for tourism operators. What is more, ecotourism is not necessarily an environmental impact-free pursuit (Buckley 2011; Kiss 2004). Ultimately, neoliberal conservation allows for private accumulation or "enclosure" of what was intended as a public good (Kelly 2011), albeit sometimes privately owned. The commodification of local culture can also lead to cultural changes especially through the elimination of certain "undesirable" components of local culture, which do not fit with a romantic "old way of life" narrative that is portrayed to tourists (Overton 1996). Moreover, working primarily through livelihood diversification, protected areas are, under a neoliberal umbrella, likely to exacerbate already existing inequalities (Holmes and Cavanagh 2016) and serve as a new way of directing money to the elite (Haenn et al. 2014). Corrupt politicians and state agents for example, may not support the establishment of protected areas "(...) without an extraordinary economic payoff" (Kelly 2011: 691) and only allow national park establishment over extractive activities in so far as the national parks provide financial resources for the state and thus the politicians and agents themselves (Kelly 2011). Also, (eco)tourism is not a readily available livelihood strategy for all (Iorio and Corsale 2010; Kiss 2004), and as such neoliberal livelihood strategies may only provide benefits to the few.

Political ecologists have put protected areas under scrutiny as protected areas, to a large extent, "(...) are implemented by different social and institutional actors (often powerful), suffered by other social groups (often not so powerful), and enjoyed by yet another set of players (tourists and scientists)" (Vaccaro et al. 2013: 255). These contradictory origins and actors raise questions of resource use and access, conflict, and justice. Yet the ways in which protected areas affect (local) people are highly contextual, as local practices, culture, protected 
area establishment/management, and politics on local, national, and subnational levels can all affect the "success" of the protected area. Nevertheless, the demarcation between those who bear the costs and consequences of protected areas and those who benefit is one defined and circumscribed by relations of power among these actors (Kelly 2011). Although evidence exists suggesting that local support for protected areas is key for their success (e.g. Pretty and Smith 2004; Sodhi et al. 2010), their establishment does not always depend on local support (Brockington 2004). For example, Brockington (2004) shows how resistance among weaker rural groups did not materialize in Tanzania, because the protected area had the support of powerful players (e.g. international environmental non-governmental organizations (ENGOs), the global public, foundations) and with effective means of controlling access to the area. Unjust treatment and oppression of local people(s) do not necessarily hamper the (ecological) success of conservation. At the same time, uniformity in agendas among powerful players is not necessarily a given, as various actors at different levels (i.e. local, regional, national, global, and/or combinations hereof) potentially have divergent interests. These differences can manifest in power struggles over which narratives should dictate future development of a landscape. The Făgăraș Mountains represents such a struggle, where conservationists with international connections hold a particular vision for the future regional development that is in stark opposition to that of local decision-makers. At the same time, the community members have heterogenous, sometimes contradictory ideas about the desired trajectory of the landscape, rooted in both a hope for rural reinvigoration to combat depopulation and a wish to stop deforestation.

\section{Context}

The Făgăraș Mountains are an uninhabited mountain range covering approximately 200,000 ha., with the mountain ridge separating Transylvania from Wallachia. The mountains are surrounded by smaller villages and some urban centers (Figure 1). The gradient of the mountain range is steep in the north with a softer slope on the south side. The mountains have considerable stands of old-growth forest, with a high density of endemic plant species and wildlife, especially wolves (Canis lupus), bears (Ursus arctos), lynx (Lynx lynx), wildcats

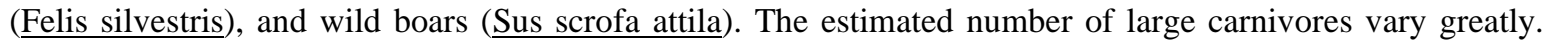
Hunters argue that the number of bears in Romania amount to over 7,000 individuals, wolves to over 5,000, and lynx to over 2,000. Conservationists have questioned this estimate, pointing out that there is no basis of knowing the actual number of individuals as there are no transparent monitoring practices in place (e.g. no genetic sampling). Similarly, the amount of old-growth forest (often denoted as "virgin" or "quasi-virgin" in the Romanian context) is also a cause of debate. Efforts have been put into mapping the extent of old-growth forest with the Romanian National Catalogue of Virgin and Quasi-Virgin Forests (Catalogul naţional al pădurilor virgine şi cvasivirgine din România). These efforts have mapped approximately 1,000 ha of virgin or quasi-virgin forests on public lands in the Făgăraș Mountains (Ministerul Apelor și Pădurilor 2019). Privately owned land is not (yet) included in the estimate. As a push for the completion and implantation of the National Catalogue, combined NGO and university efforts have developed their own initial Potential Primary Forests Map of Romania based on satellite images, estimating a potential 61,423 ha of old-growth forest in the Făgăraș Mountains (Kathmann et al. 2017).

The northern side of Făgăraș Mountains are designated an EU Natura 2000 Site of Community Importance (SCI), including the communities inside the SCI. On the southern side, the mountains are designated as a Natura 2000 Special Protection Area (SPA). The area is characterized by a mosaic of different land ownership including lands owned by private landowners, the state, municipalities (pădure comunală), as well as lands owned by the commons (obște in the south and composesorate in Transylvania). Differences between pădure comunală and obște and composesorate should be noted. Residents of the municipality are, in theory, entitled to equal shares and access in pădure comunală, which is managed by the municipality in collaboration with the appropriate forestry entity (which can be private or public). While obște and composesorate are collective forms of landownership, the management of these varies considerably between individual associations. Noteworthy is that it is not a collective of land shares put together, but a system based on the number of votes one holds and the quantity of products that can be extracted from the land (Măntescu and Vasile 2009). However, obște and composesorate landownership still exists within the project area and have been "(...) designed by law to remain 'fixed', attached to the communities and not blown by the wind of the 
market into foreign hands" (Măntescu and Vasile 2009: 103). These commons typically provide the shareholders with either firewood or cash. Firewood is a pivotal resource for community members, as not all communities have access to natural gas and within the communities where natural gas is available, not all households are connected to the gas pipe, since costs are often prohibitive. Many therefore still depend on firewood as a primary or secondary source of heating.

During the communist regime, privately owned lands and obște and composesorate were nationalized and collectivized. Bigger farms were merged into "state farms", which received state subsidies, while smaller farms were joined into "collective farms" (CAP), which did not receive them. The state and collective farms were, in this time period, characterized by monocultures and changes in the agricultural species composition. During Ceausescu's rule (1965-1989), developing heavy industry became a political priority as a way of dealing with the "backwardness" of the countryside (Dorondel 2016; Hitchins 2014). At the same time, the forest was preserved for hunting grounds (Walentowski et al. 2013).

Following the Romanian Revolution in 1989 not all of the collectivized lands were re-privatized in full, if at all, and land management policies were largely dominated by neoliberal ideologies. This shift away from collective farming and nationalization of lands is exemplified by the first post-communist land reform passed in 1991 (Land Law 18/1991) and the second in 2000 (Land Law 1/2000). The first law established land commissions at the local level, typically consisting of mayors responsible for implementing land and forest restitution. These reforms ultimately led to the privatization of land, based on ideas of restoring historical justice - that is, restoring landownership to former landowners, excluding the previous Roma slaves, today commonly referred to "gypsies" although this term refers to two groups of people, both Roma and Rudari people (Dorondel 2016). Rudari people are a minority in Romania, who speak Romanian and are often associated with forestry work. Despite a different ethnicity, language, culture, and self-identification, the Romanian state considers Rudari as Roma (Dorondel 2007; Hansson and Trabelsi 2017).

With the transition from national to private control followed deforestation as locals' newly acquired forests allowed for making quick profits by either selling their forest, or the rights to the timber resources (Dorondel 2016). Local as well as international forestry interests capitalized on this development, resulting in increasing deforestation rates. (Il)legal logging and deforestation issues are still prevalent in the area today.

In Romania, EU accession also brought about a new political strategy regarding conservation. As in many other ECE countries, with the accession of Romania to the EU in 2007 conservation took a new form. Where ECE environmental management was formerly dominated by central planning and top-down approaches, new member states' conservation efforts were characterized by an increase in protected area designations, decentralization of protected area management, and restructuring of conservation policies (Yakusheva 2017). In Romania, EU conservation schemes took managerial precedence over Romanian conservation goals (Iojă et al. 2010). While land reforms worked towards privatization of land, becoming part of the EU also led to the designation of public protected areas - a simultaneous privatization and public protected area designation strategy (Dorondel 2016). One result was the designation of the Făgăraș Mountains as a protected area under the EU-wide Natura 2000 protected area network in 2007. Today, the Făgăraș Mountains are facing a new potential landscape transformation: becoming an International Union for Conservation of Nature (IUCN) category II, a national park. Adjacent rural, forest and farming-dependent communities could potentially be affected by a national park designation and the land use restrictions that follow, especially in the case of firewood provision and restrictions on livestock herding. The complex landowner mosaic in the area prohibits a complete purchase of the 200,000 ha of land that the Făgăraș Mountains cover, thus the potential national park is reliant on management agreements between the different actors (municipalities, obște and composesorate, private landholders who are not willing to sell, the state), based on compensations being carried out between the conservationists and various landowners in the area.

Official census data estimates a total of approximately 70,000 people living in the three counties (Argeș, Braşov, and Sibiu) where I carried out fieldwork. Interviews with the local mayors revealed that the de facto population is likely much lower than the official data indicates. A mayor in one of the most densely populated municipalities estimated that only $60 \%$ of the official residents had their daily activities in the municipality. The remaining $40 \%$ were presumed to live elsewhere, despite having an official address in the area. Not unlike 
the rest of Romania, I frequently encountered people who have their primary work activities abroad (Spain, Italy, Germany) or people whose family members have permanently emigrated to other parts of Europe or North America. Relocating to urban areas, especially among younger people, is also a common phenomenon and the area is characterized by an aging population.

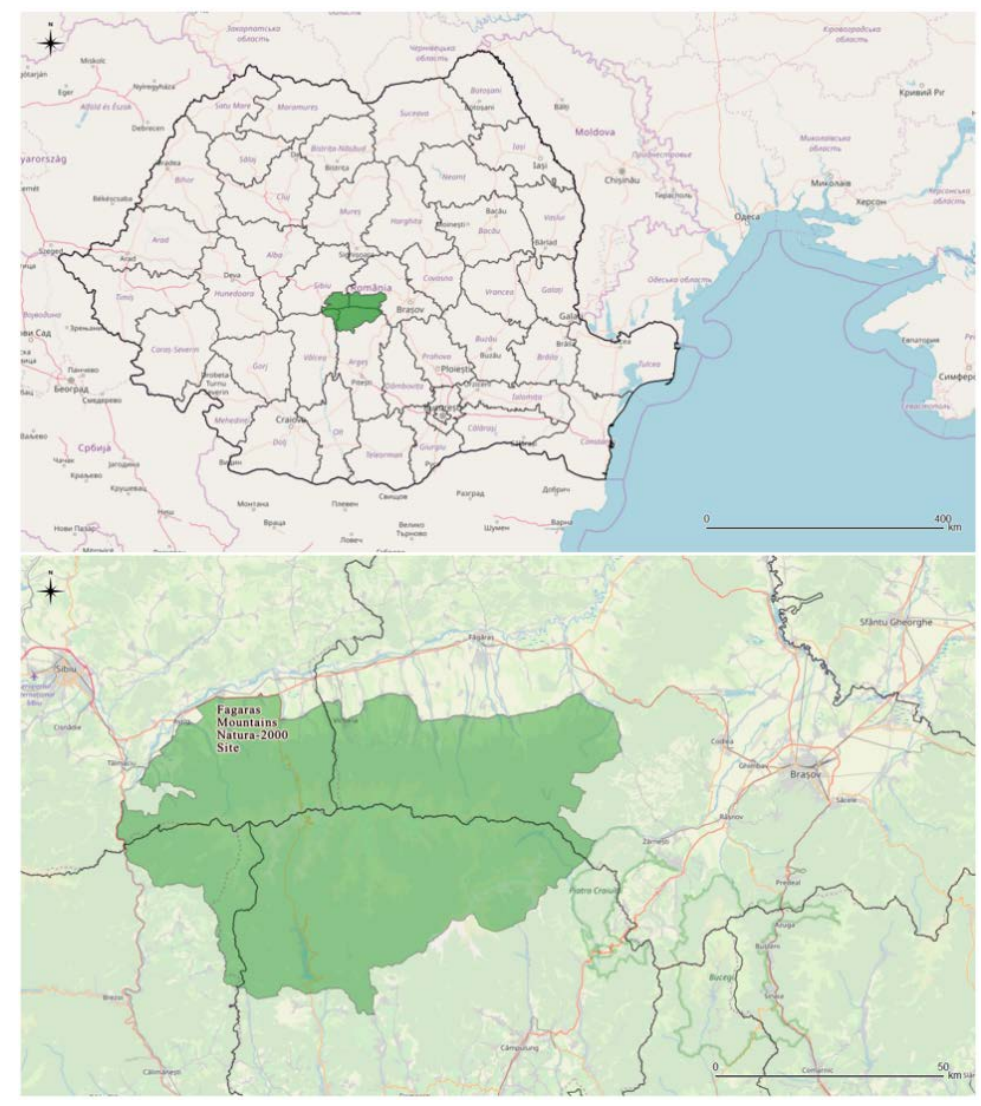

Figure 1: Study area: the Făgăraș Mountains. Source: Openstreetsmap and European Environmental Agency.

As I will show, local community members do not form a homogenous group with one common identity and one unidirectional conservation narrative. Rather, the narratives employed by local community members are complex, often conflicting, and reveal the diversity in opinions and alliances held in local communities (Horowitz 2011). In this research, I use the umbrella term local community members to denote people living in the area around the Făgăraș Mountains who employ various livelihood strategies. The livelihood makeup of these communities is complex and characterized by occupational pluralism and semi-subsistence peasantworkers who pursue various livelihood strategies simultaneously. That is, besides having various types of waged employment, the majority of local community members I surveyed also indicated that they have livestock (73\%), orchards (69\%), and grow produce (87\%) to meet own needs. For example, besides running the local guest house, one interviewee was also the principal of the local school, part of the mountain rescue team, and related to the vice-mayor. This illustrates the complexity of the various social ties and relations that comprise the social makeup of these communities, where a person may hold various positions and represents different interests. 
Resource dependence on the Făgăraș Mountains themselves is generally low and livelihood strategies carried out in the mountains are primarily herding of sheep or collecting berries, mushrooms, and nuts either for private consumptions or, in the case of Rudari people, as a source of income under employment in private companies. Firewood-dependent people primarily receive firewood from the municipality, from obște/composesorate if they are part of one, or they buy firewood from private companies. Obtaining permission to cut wood from one's private forest is a highly regulated activity. After obtaining the necessary permits to harvest trees, a forester will assess the wood stock on the private lands, mark the trees which can be cut, and then the harvesting can proceed, under the supervision of the forester. Forest stocks of 10 ha or less have an upper harvesting limit of $5 \mathrm{~m}^{3} /$ ha/year. Harvesting trees on larger forest areas must be done according to the forestry management plan.

\section{Methods}

In order to understand the different conservation narratives employed by conservationists, local decisionmakers, and local community members, I employed a mixed methodology approach that included semistructured interviews, a questionnaire, document analysis, and participant observation. After an initial visit to the study area in March 2017, I spent three weeks between September - October 2017 in the counties of Braşov and Sibiu in the north and Argeș in the south. I spent and additional four months in these areas between August - December 2018.

During the first field season I conducted semi-structured interviews with twenty-nine key interviewees to identify issues relevant to the communities. Informed by these interviews, I employed a mixed methods approach $^{2}$ and conducted interviews with an additional twenty-six interviewees alongside administering a proportionate random sampled quantitative questionnaire $(n=644) .{ }^{3}$ The questionnaire consisted primarily of closed-ended questions on a five-point Likert scale (strongly disagree; disagree; neutral; agree; strongly agree), focusing on issues of land use/management in a historical and current context, and the proposed national park (Table 1). The questionnaire was pretested on a convenience sample and translated from English to Romanian. ${ }^{4}$ The questionnaire included the following sections:

1. Types of activities undertaken in the Făgăraș Mountains

2. Knowledge regarding Făgăraș Mountains' designation status

3. Perceptions of current land management

4. Perceptions of land management in historical perspective

5. Perceptions of the proposed national park

6. Acceptability of potential restrictions resulting from national park designation

7. Information regarding livelihood strategies

8. Demographic information

To do this, I carried out interviews with people whose primary activities were operating guesthouses, farming, sheep herding, home-making, as well as teachers, retirees, local historians, local decision-makers (mayors and vice-mayors), ENGOs present in the areas, civil servants at a national level involved in forestry, protected areas, and hunting, in a total of eleven different smaller communities (average size ranging from 1,000-6,000 citizens). In the following I will refer to people by an assigned pseudonym and their primary function, to allow the reader to understand their position within the communities.

\footnotetext{
${ }^{2}$ All data collection was approved by the Interdisciplinary Committee on Ethics in Human Research at Memorial University.

${ }^{3}$ Response rate of $30 \%$.

${ }^{4}$ To ensure correct translation of the questionnaire it was reviewed by three separate native Romanian speakers.
} 


\begin{tabular}{|c|c|c|c|c|c|}
\hline $\begin{array}{c}\text { I believe that the proposed } \\
\text { Făgăraș Mountains National Park } \\
\text { will... }\end{array}$ & $\begin{array}{l}\text { Strongly } \\
\text { Disagree }\end{array}$ & $\begin{array}{l}\text { Moderately } \\
\text { Disagree }\end{array}$ & Neutral & $\begin{array}{l}\text { Moderately } \\
\text { Agree }\end{array}$ & $\begin{array}{l}\text { Strongly } \\
\text { Agree }\end{array}$ \\
\hline ... restrict fishing inside the park & 1 & 2 & 3 & 4 & 5 \\
\hline $\begin{array}{l}\text {... restrict wood cutting inside the } \\
\text { park }\end{array}$ & 1 & 2 & 3 & 4 & 5 \\
\hline $\begin{array}{l}\ldots \text { restrict the collection of berries } \\
\text { and mushrooms inside the park }\end{array}$ & 1 & 2 & 3 & 4 & 5 \\
\hline $\begin{array}{l}\ldots \text { restrict having grazing animals } \\
\text { inside the park }\end{array}$ & 1 & 2 & 3 & 4 & 5 \\
\hline ... restrict hunting inside the park & 1 & 2 & 3 & 4 & 5 \\
\hline$\ldots$ reduce access to roads & 1 & 2 & 3 & 4 & 5 \\
\hline
\end{tabular}

Table 1: Sample questions from the questionnaire.

The first period served as an exploratory field season to identify issues around land use and management within the context of the newly proposed conservation area. As this work served as the foundation for future research, I wanted to understand the differences in use of the Făgăraş Mountains, the challenges and opportunities that might result from the proposed conservation area, and how different actors situate themselves in regard to this potential conservation development.

In this article, I will draw on the qualitative data from interviews and the voluntary comments left on the questionnaires ( $n=264)$ alongside some items pertaining to the development of ski slopes ("I would support ski slope development in the Făgăraș Mountains ${ }^{5 ")}$ and perceptions of potential restrictions resulting from national park designation (see Table 1).

Except for a few interviews conducted in 2017, I worked with the same local translator throughout each field season. All but five interviews were recorded, transcribed and translated from Romanian to English. I used NVivo 12.2.0 to code the interviews, questionnaire comments, and fieldnotes. Using inductive thematic coding (Braun and Clarke 2006), I first identified statements pertaining to different conservation narratives across respondent groups (conservationists, local decision-makers, and local community members) and then coded the statements according to the following themes: tourism (skiing, eco-tourism, protected area visitation, rural invigoration); restrictions (livelihood strategies, firewood, development), and deforestation (illegal logging, logging, wood mafia ${ }^{6}$, thieves, protected areas). Each individual interview was also analyzed to identify any seemingly contradictory statements (e.g. appreciation for protected areas, but not supporting the designation of national parks).

\section{The becoming of a national park?}

The political and socio-economic context of the area deeply inform narratives around the proposed conservation initiative. Three main themes dominate these narratives: tourism, anticipated livelihood

${ }^{5}$ I asked this question using a five-point Likert scale ranging from "strongly disagree", "disagree", "neutral", "agree", "strongly agree".

${ }^{6}$ The media has reported an increasing number of violent encounters between large-scale illegal loggers (the so-called "wood mafia") and foresters across Romania in recent years (Ilie 2019; McGrath 2019). Although no such cases have been reported in the Făgăraș Mountains, locals still expressed concerns related to the wood mafia's activities. 
restrictions, and deforestation. These themes manifest differently across actors. At one end of the spectrum are the conservationists, who include various regional and international ENGOs. This group holds power in that they can purchase lands, have international connections, and are part of global conservation movements. As such, the vision of the conservationists mirrors the global discourse on biodiversity conservation and addresses audiences beyond the local scale, including foreign "eco"-tourists, philanthropists, and global publics. On the other end of the spectrum are local decision-makers, consisting of local mayors and vice-mayors, who hold positions of power at a local level with regional and national connections, and possess the ability to create resistance to the proposed conservation area at a regional level. The results are summarized in Table 2 and described below. With the exception of rural and heritage tourism, the conservationists and local decisionmakers employ narratives that are in stark contrast to each other. In between these two groups are the local community members, who hold diverse perspectives on the initiative. While the narratives among conservationists and local decision-makers were uniform, some local community members employed multiple, and sometimes conflicting, narratives to describe their visions for the area.

\begin{tabular}{|c|c|c|c|}
\hline & Conservationists & $\begin{array}{l}\text { Local Community } \\
\text { Members }\end{array}$ & Local Decision-Makers \\
\hline \multirow[b]{2}{*}{ Tourism } & $\begin{array}{l}\text { Wildlife/eco-tourism; rural } \\
\text { tourism }\end{array}$ & $\begin{array}{l}\text { Heritage tourism; agro- } \\
\text { tourism; rural tourism; } \\
\text { skiing tourism; eco-tourism }\end{array}$ & $\begin{array}{l}\text { Skiing tourism; agro-tourism; } \\
\text { rural tourism; heritage } \\
\text { tourism }\end{array}$ \\
\hline & \multicolumn{3}{|c|}{$\begin{array}{l}\text { With regard to tourism, local community members employ narratives that are sometimes } \\
\text { contradictory, and reflect both conservationists and local decision-makers. }\end{array}$} \\
\hline \multirow[t]{2}{*}{ Restrictions } & $\begin{array}{l}\text { Restrictions are not framed } \\
\text { as bad. The narrative } \\
\text { focuses on the ecological } \\
\text { impact of human activity - } \\
\text { especially logging and } \\
\text { herding. Local livelihood } \\
\text { needs are framed as } \\
\text { important and conservation } \\
\text { enterprises are seen as a } \\
\text { viable strategy for the } \\
\text { future. }\end{array}$ & $\begin{array}{l}\text { Fear of restrictions prevail } \\
\text { mostly regarding local } \\
\text { livelihoods (especially } \\
\text { firewood supply), potential } \\
\text { impact on the built } \\
\text { environment, and in } \\
\text { relation to access. }\end{array}$ & $\begin{array}{l}\text { Restrictions are believed to } \\
\text { hamper all development, } \\
\text { especially regarding the built } \\
\text { environment and skiing. }\end{array}$ \\
\hline & \multicolumn{3}{|c|}{$\begin{array}{l}\text { Local decision-makers employ the strongest restriction narrative. The local community } \\
\text { members' narrative is not unidirectional nor as strong as the local decision-makers, yet } \\
\text { the narrative is more connected to the local decision-makers' than the conservationists'. }\end{array}$} \\
\hline \multirow[t]{2}{*}{ Deforestation } & $\begin{array}{l}\text { Deforestation and illegal } \\
\text { logging are at the core of } \\
\text { the narrative and serves as } \\
\text { the chief motivation for } \\
\text { establishing a national } \\
\text { park. }\end{array}$ & $\begin{array}{l}\text { Recognizes deforestation } \\
\text { as a problem of concern. A } \\
\text { national park could } \\
\text { potentially hamper this } \\
\text { development. }\end{array}$ & $\begin{array}{l}\text { Deforestation is not } \\
\text { considered an issue within } \\
\text { the jurisdictional boundaries } \\
\text { of the municipalities and do } \\
\text { not form part of the local } \\
\text { decision-makers' narrative. }\end{array}$ \\
\hline & \multicolumn{3}{|c|}{$\begin{array}{l}\text { Deforestation is part of the chief narrative among conservationists. This is somewhat } \\
\text { reflected in local community members' narrative, where a national park is seen as a } \\
\text { potential "remedy". Local decision-makers are outside of this narrative. }\end{array}$} \\
\hline
\end{tabular}

Table 2: Conservation narratives overview. 


\section{FMNP and Tourism}

At a local decision-making level, the focal point is development. In this view, development means enhancing tourism infrastructure and the upkeep of the region's major tourist attraction, the Transfăgăraşan, the only road running north-south through the mountains, built by the communist regime for military purposes between 1970-1974. Besides forestry roads, this is the only road going through the proposed national park area. Due to the high seasonality in tourism, a primary concern is establishing winter tourism, especially building ski slopes in the mountains. Local decision-makers (and occasionally by community members) look to Austria as a desirable model for (skiing) tourism development and the Făgăraș Mountains are generally believed to be competitive with Austrian skiing. As Vlad, a local mayor, mentioned when asked if skiing would benefit his community:

I think that for the winter season it would be the best option indeed. So, in those months, previously without visitors, one could have tourists here and a resort for visitors could offer opportunities to people of any age. People are looking for places like this, cozy, quiet, with very fresh air, nice nature and landscapes. (Vlad, mayor, September $26^{\text {th }}$, 2017)

This vision is in complete conflict to that of conservationists. Skiing is a competing land use to that of conservation and if ski slopes were to be developed, it would mean cutting down (potential) old-growth forest and disrupting the habitats that conservationists are looking to preserve. For conservationists, ski resort development would represent a potential coup de grâce for the wilderness reserve they envision. Protected areas are often seen as a panacea for mitigating habitat loss, putting a stop to extractive activities, and conserving biodiversity. The case of the Făgăraş Mountains is no different: establishing a well-managed national park is seen by conservationists as a means to preserve the last stronghold of large carnivores in Europe, old-growth forests, and endemic plant species, while ensuring livelihood diversification through "eco"-tourism. This vision of "wilderness" is illustrated by Mihai who works for an international ENGO:

Basically, I'd like to see the Făgăraş Mountains remaining one of the wildest areas in Romania and Europe (...) That is, no intervention, left to their own evolutionary dynamics. And the rest of the forests outside should be managed in a responsible and sustainable manner. So not intensive use for commercial logging, but let's say used for the benefit of local communities: employment, things like that. Basically, it resembles a national park. (Mihai, conservationist September 22nd 2017)

The narratives on tourism manifest as a clear dichotomy between skiing, supported by local decisionmakers, and ecotourism supported by the conservationists. Six of the ten local decision-makers who participated in this research expressed support for developing ski slopes in the area. All but one of the six were against the establishment of a national park, with the primary reasons being the restrictions resulting from such a designation and suspicion around the intention of the conservation organization and its philanthropists. The one decision-maker who was not directly opposed to the potential national park designation thought the park could increase tourism to the area, especially in the case of bison (Bison bonasus) reintroduction, which is on the agenda of conservationists. Four of the mayors did not immediately position themselves against the proposed park and recognized that there may be some potential (tourism) benefits from the project, without elaborating on how. They did not talk about skiing.

Alongside biodiversity conservation, conservationists also employ climate change as an argument against developing ski slopes, as the snow cover is decreasing. This argument is not accepted by the local decision-makers, who, overall, do not believe climate change to be a cause of concern for future skiing opportunities.

The narratives employed by local community members reflect the heterogeneity of this group. Among local community members, "nature" forms a greater part of the development narrative than among local 
decision-makers. However, local community members emphasize different types of tourism: to some, enhancing the number of tourists is central to their narrative, regardless of the type of tourism in question. To others, the desirable type of tourism is centered around nature and heritage, especially so-called "agro"-tourism, which denotes a certain type of rural farm tourism based on the preservation of rural life and capitalizing on this lifestyle by offering "authentic" experiences to tourists through for example the consumption of "pure" and "authentic" local produce. While local decision-makers question the overall feasibility of this type of tourism, they, as well as the conservationists, recognize the selling point that rural life represents.

While positions of support or opposition to development initiatives can reflect anticipated outcomes and distribution of benefits, divisions can also occur among actors who could potentially be beneficiaries of either type of future landscapes. For example, when talking about protected areas and Bâlea Lake, a lake located on the Transfăgăraşan in the Făgăraș Mountains (Figure 2), Raul, who works for a larger guesthouse complex, expressed his dissatisfaction with the area's current protection status:

[a protected area] is stupidity. The bureaucracy prevents you to make ski slopes. The government implemented these protected areas so that people can't develop the area. (...) Maybe it works on paper but not in real life. At Bâlea Lake a national park could be established. (...) Up there [pointed towards the mountains], Natura 2000, protected areas, they're bullshit because you can't do anything in the area. You can make protected areas, but not where there are thousands of tourists! Either/or. (Raul, tourism operator, September 27 ${ }^{\text {th }}$, 2017)

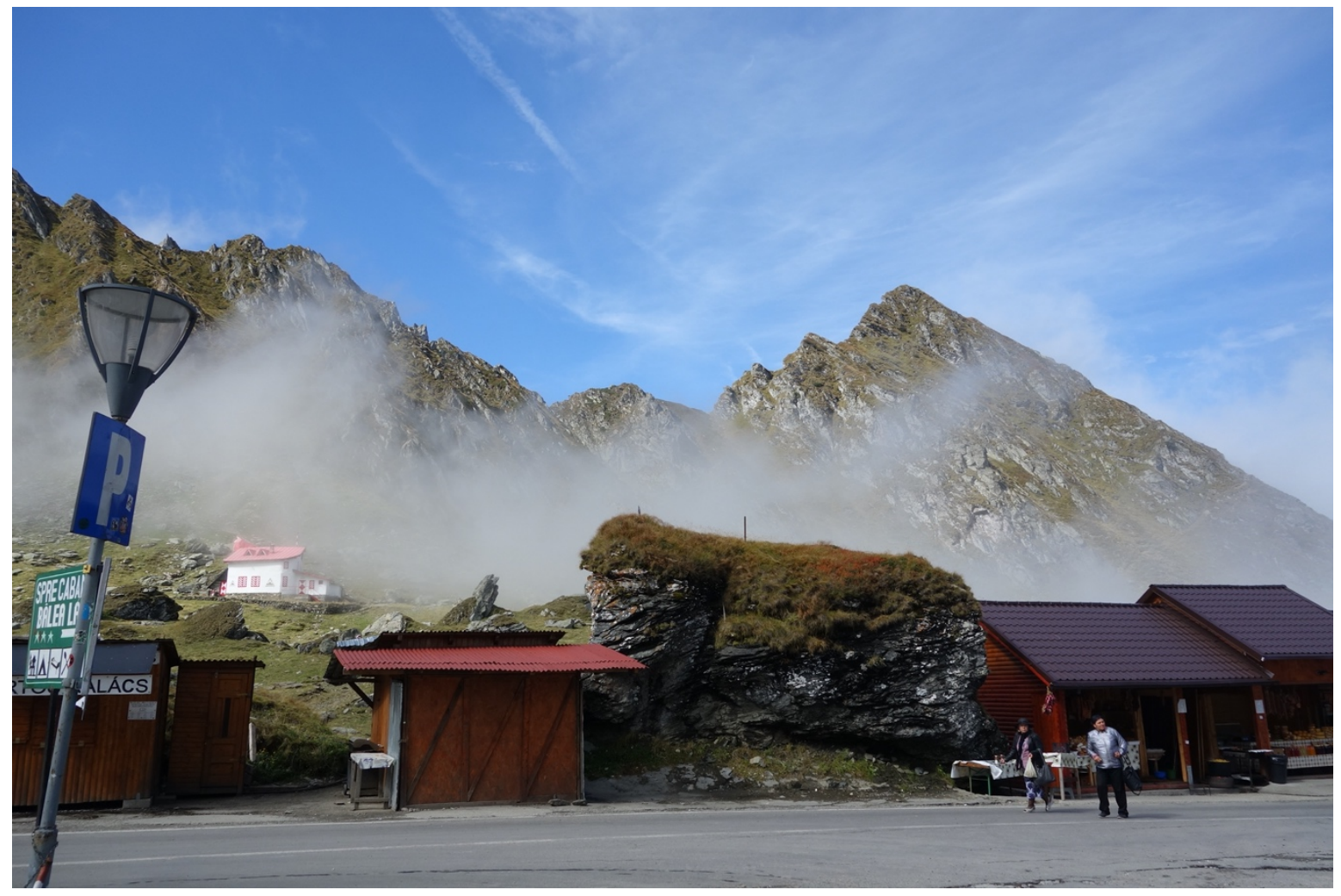

Figure 2: Market booths at Bâlea Lake. Source: Marie Louise Aastrup

Here, conservation and development are seen as incompatible. This is, however, far from the dominant narrative among local community members, who do not regard the conservation agenda as conflicting with potential skiing development. The development of ski slopes is largely supported by local community 
members. The questionnaire data indicates that $74.5 \%$ of the respondents either agreed or strongly agreed with the statement "ski slopes should be developed in the Făgăraș Mountains." This mirrors the narratives of local community members as expressed in the interviews. Here, supporters of the potential park do not see skiing as disruptive, but rather a desirable landscape vision alongside that of a national park. Ioana, a local guesthouse owner, reflects on the conflicting plans for establishing skiing and a national park:

It would be very good if they opened ski slopes, but I wouldn't know where. It would be very good for tourism, there would be more offers in the wintertime (...) Yeah it could be [a good idea to establish a national park] to protect the area and the environment because at Bâlea Lake they are building new stuff and it's not good to do that on the mountain. Better to leave it wild (...) Bâlea Lake needs to stay wild, now there are many constructions that ruin everything, the beauty is destroyed. It shouldn't be allowed to make that food market on the road at the lake. Before there was only a couple of lodges, not as many as nowadays. (Ioana, guesthouse owner, September $29^{\text {th }}$, 2017)

To Ioana, skiing does not encompass a negative, disruptive type of development that the small market booths do. For local community members positioning themselves against the national park narrative, conservation is understood to undermine any plans for skiing development. Like Ioana, there are also locals who are supportive of both. As such, the local understandings of what a protected area entails are far from that of conservationists. In this sense, the positions of local community members occupy a middle ground between the two dominating landscape ideologies, where the focal point is reinvigoration of the area through tourism.

\section{FMNP and restrictions}

A central narrative for local community members revolves around potential restrictions on access to resources in the park. A national park is understood to restrict certain livelihood activities such as fishing (65.2\% of respondents), picking of berries/mushrooms/nuts (47.5\%), grazing animals (49.5\%), and hunting (65.4\%). One-third (32\%) also believe that a national park will reduce road access. It should be noted that, despite firewood dependence and sheep herding, local livelihood dependency on the area is low. Settlements are located outside the borders of the proposed park and so are the agricultural lands. However, fear of a Yellowstone model is prevalent, especially among local decision-makers and local community members. These fears do not only relate to loss of livelihoods, but also a fear of being erased physically as well and rhetorically from the landscape. One man refused to participate in the study since he told me that his community was one of herders, always had been, and should continue to be so, and therefore he did not want to engage in any conversations about a potential park. This illustrates a fear that other interviewees voiced - one of changing the cultural landscape of the communities.

Restrictions are framed as desirable (stopping the wood thieves) and undesirable (restricting livelihoods, mobility, and culture). For example, loss of access (e.g. being allowed to walk in or enter the area) is a concern that surfaces in 22 of the voluntary comments provided on the questionnaire and in the interviews. This is illustrated by the following questionnaire comment:

I do not agree with a national park in the Făgăraș Mountains because we will no longer have access to walk through the forests, there will be no more firewood and we will not be allowed to pick the forest fruits. (Questionnaire no. 576)

Private consumption aside, picking of mushrooms, nuts, and berries is primarily carried out by Rudari people and the products are sold either to commercial enterprises, at roadside stands, or to other community members. Any potential livelihood restrictions resulting from the park designation would likely impact Rudari people and shepherds the most. These are also the two groups of people in the area with low employment security and lower incomes. As studies elsewhere note, restricting access can lead to loss of resources critical 
to livelihood strategies and culturally important practices, especially for marginalized people and minority groups (Cundill et al. 2017; Salafsky and Wollenberg 2000), such as Rudari people and others who rely on access to local resources. Gathering of forest products (excluding firewood) for private consumption is likely not going to be impacted by a potential national park designation as national parks typically have zonings that allow for different levels of human activities.

The restrictions narrative is strongest among local decision-makers. While local community members highlight issues of firewood supply, local decision-makers articulate park restrictions as hampering every kind of development and effectively also tourism. Stefan, a vice-mayor in one of the local municipalities, holds strong opinions about protected areas:

[Protected areas are] another trouble, another trouble (...) I don't really agree with them. (...) National parks cut down all investments, preventing all exploitation of the forest, even dead or fallen trees. No more hunting, no more building. It pretty much stops all possibilities. I also know this group of interest, foreign investors, that wanted to buy up forest land around here. (...) I don't really know, I don't think there's anything good behind it (vice-mayor Stefan, September $\left.25^{\text {th }}, 2017\right)$

Restrictions also form part of the conservationists' narrative, but here restrictions are situated as an important step toward preserving the wild beauty of a landscape that "historically have had minimal human presence." This is especially prevalent for the case of (il)legal logging, deforestation, sheep herding, and hunting (especially of large carnivores). My data indicates that only very few local community members take part in hunting activities and that only few (16\%) are concerned about the potential restrictions on hunting that a national park could cause. The Romanian state issued a hunting ban on large carnivores in 2016, which has also spurred conflict especially between conservationists and hunting associations, but it is also a cause of concern for some local decision-makers to whom hunting forms part of the tourist attraction offered in the area.

Local community members are less welcoming to any potential restrictions on livestock grazing and herding (32\% indicated that they find this restriction unacceptable). While the conservationists recognize and integrate local livelihood strategies into their agendas, herding is one livelihood component that is framed as problematic due to its ecological effects. The narratives around herding situate local community members and local decision-makers in one camp and conservationists in another.

\section{FMNP and deforestation}

The transition period from communism to neoliberalism opened for the possibility of making quick profits by selling timber extraction rights. When the first land law (18/1991) was passed, previous landowners were assigned one hectare of forest land regardless of the size and location of their historical property. In many instances, this meant receiving lands that, for geographical reasons, were inaccessible to the new owners. This, combined with the economic hardship facing many households in the transition period, led to selling of property or timber rights to logging companies. Mirela, a homemaker and guesthouse owner, is among those who sold her forest at what she believed to be a low price: $2,250 \mathrm{~m}^{2}$ of forest for a current value of approximately US $\$ 450$ (around 2 million old Romanian Lei). For the two hours we were sitting in her yard, eight trucks drove by us with full loads of wood. Noticing this, Mirela voiced her concern about deforestation, as she believed the logging activities, she observed to not be fully legal and that reforestation only rarely occurs:

They are actually not just exploiting but shaving down the forest. It is never entirely legal, maybe a bit of it is legal. (...) The problem here is that they do it through old people, with or without papers and you lose their track. They offer some money to people for their forest, only with a verbal agreement, no papers, then they cut down the trees. (Mirela, homemaker, October $14^{\text {th }}$, 2018) 
She explained that, following the Romanian revolution and privatization of lands in the 1990s, several of the elderly people in the village had been led to believe that their forests were sold, when in reality they only sold the timber rights. In those cases, the actual owners were (unknowingly) legally bound to take the appropriate reforestation measures (Bouriaud 2005). When this did not happen, the forestry department could not hold the actual owners (often poor, elderly people) accountable, and the forestry companies who had caused the deforestation had often left the area, closed the company, or moved abroad. The result was deforested areas with no reforestation in sight.

It is exactly this context that spurred the conservationists' vision of creating a national park: as a means of protecting the remaining old-growth forest, reforesting previously clear-cut areas, and ending illegal logging. This resonates with local community members. A total of 35 people volunteered written comments on the questionnaire on stopping the "wood thieves" and the park's potential in doing that. For instance:

Starting a Făgăraș Mountains National Park would be a unique solution to stop the illegal logging and to protect the plants and animals from the forest. The lands management should be done by competent and fair people, not by thieves and mobs. (Questionnaire no. 64)

The concerns about deforestation do not mirror the narratives employed by local decision-makers. While recognizing that deforestation may be an issue in "other" geographically indeterminable areas, local decision-makers are not concerned about deforestation within their own juridical boundaries. The reasons for this are many. Designating the area as a national park will restrict forestry activities and this is a cause of concern, especially regarding local firewood supply. Local decision-makers may also be reticent to articulate any potentially benefits of the park (e.g. combatting deforestation) as this would undermine their own chief narrative, namely developing ski slopes. One local-decision maker completely dismissed the notion that a national park could bring any benefits to an area whatsoever. When asked to elaborate, he refused. Another reason why local decision-makers may not include deforestation in their narratives could be found in the micropolitics of the communities. I sometimes encountered stories that implicated certain local-decision makers in logging and deforestation activities. This has also occurred in other parts of Romania, where scholars have shown that local administrations have been engaged in forestry and illegal logging activities (Bouriaud and Marzano 2014; Dorondel 2016; Vasile 2008). While my data does not support any conclusions on local decision-maker's involvement in illegal logging and forestry activities, such potential involvement could explain some of their opposition to the proposed national park.

\section{Discussion and conclusions}

In 2016, a year prior to my first field season, an association of landowners gathered with local decision-makers and community members to discuss the proposed national park. Two meetings took place, out of which one was video recorded and later broadcasted at a local TV station which airs in Tara Făgăraşului, in the northern side of the Făgăraș Mountains. Vlad, a local mayor recalls:

We had a meeting (...) with all the mayors of the area regarding the conservation organization and its projects. They went a bit too far, it is too ambitious and somehow abusive, they wanted somehow to take over people's properties to include those in the national park: but it is private property, they can't just mislead people and not care about it. The meeting was against this conservation organization. There was a discussion between local authorities and the landowner association, and it just went too far. (Vlad, local mayor, September $26^{\text {th }}$, 2017)

Vlad was not the only person recalling this meeting. Others mentioned it as well, in the context of how a national park would restrict and completely shut down all investments. At this meeting, the participants (local decision-makers, the landowner association, some local community members) "(...) signed some papers and agreed not to have a national park around here" (Stefan, vice-mayor, September $25^{\text {th }}$, 2017). This document 
was later published on the landowner association's website in an article titled "Save Romania's territory! "land grabbing" in the heart of the country," part of a series of articles opposing the proposed park. This emerging opposition hampered the national park front-runner organization's collaboration with local decision-makers. This meeting resulted in a lawsuit over the spreading of misinformation between the landowner association which initiated the meeting and the national park front-runner organization, which later won the lawsuit.

As this episode shows, untangling the various conservation narratives that emerge among different key actors highlights the ideologies, (power) relations, and values that characterize the different actors involved. These narratives can also fuel conflict between actors exercising different degrees and forms of power through their connections at different scalar levels (Büscher 2012; Neumann 2009). In this case, the key actors include the local people who live around the mountains, the local decision-makers who guide municipal development, and the conservationists who are located in the area, in urban centers in Romania, and abroad. These actors exercise different types of power by fostering relationships at different scalar levels that are beneficial to them, with actors who are supportive of their conservation narratives. As my research shows, these scalar arrangements are constructed (Neumann 2009; Walker and Fortmann 2003) in ways in which rural landscapes become part of local, regional, national, and international management schemes (Vaccaro et al. 2013) - be they around "wilderness" or "development", the two conflicting narratives in this case.

The different actors' abilities to produce particular (contested) outcomes and relationships relates, as the Făgăraș Mountains case illustrate, to the actors' power relations and how they mobilize at certain scales. Fostering relations across scalar levels is thus a strategy that different actors employ (Brown and Purcell 2005; Campbell 2007), which also reveal the power relations and the type of power actors can exercise. At the local and regional level, mayors and vice-mayors hold power and can utilize connections at these levels to support their agendas. Conservationists hold a different type of power and have different audiences. While conservationists can acquire land and enforce restrictions on use and access on their lands, they do not hold the same local power as elected decision-makers who are supported by powerful politicians at regional and national levels. However, in 2016 the front-runner organization and the technocratic government at the time signed a memorandum of understanding for the potential establishment of the Făgăraș Mountains National Park, illustrating the connections between conservationists and government officials and how conservationists also have the potential to influence national policy development. The signing of this memorandum caused a communication breach with local community members, with some confusion as to whether or not a national park had already been designated.

In between conservationists and local decision-makers is the heterogenous group of local community members, who have diverse visions and employ various conservation narratives. This is key in understanding what the "local" perspective may entail as local community members use different conservation narratives supportive of different visions for the future Făgăraș Mountains. Dissecting the "local" would aid an understanding of the different power relations that local community members are part of, as local community members include marginalized groups such as Rudari, shepherds, farmworkers who formerly worked on collective farms, urban dwellers enjoying their retirement in the countryside, business owners, and local public workers among others.

As my research shows, different actors' conservation narratives also illustrate their political interests (Campbell 2007). The different actors' conservation narratives can reveal points of contention and potential "sites" of conflict over the desired type of landscape and the meanings ascribed to the landscape, as well as their visions for the future of Făgăraș Mountains. There is no single, shared vision, nor one dominating conservation narrative that serves as a common ground between these actors, who have different political connections and abilities to dictate the future of the area. As such, the narratives also tell us about the ideological standpoints and political agendas of the actors, as different actors are likely to support initiatives which they believe to be beneficial to themselves (Horowitz 2010; Walker and Fortmann 2003). The overarching narrative for conservationists is one of establishing a new national park for biodiversity conservation and ecotourism. This vision spurs narratives over restrictions among local decision-makers and local community members alike. The chief narrative among local decision-makers is about developing ski slopes, a narrative that conservationists reject as nonsensical due to threats of snowmelt caused by climate change, and they position themselves against because it goes against their vision of environmental stewardship. 
The agenda(s) among local decision-makers focuses on development and rural invigoration primarily through increasing tourist infrastructure. Local decision-makers' primary concern is about local economic development, for which ski development is seen as the solution.

The political nature of the narratives is most evident among the actors who have greater power to influence the future of the landscape. The agenda among conservationists is one of protecting wilderness through designating the area as a national park. Although "conservationists" as a group of key actors include various environmental NGOs, they represent a more homogenous narrative than the other two groups. Conservationists also employ this narrative through various means as they purchase land for protection, campaign regionally, nationally, and internationally, and establish connections at a national and subnational level. This illustrates the way in which neoliberal conservation schemes operate through private initiatives. The conservationists' international connections are primarily related to financial support received from international philanthropists, collaboration with internationally based organizations, and communication through various media with environmentally concerned global publics.

Political ecology elucidates the ways in which a national park can change the ways of living with the forest - by both eliminating some ways of life and making new ways of living with the forest possible. A political ecology framework also aids our understanding of how certain powerful political actors (i.e. conservationists) are able to dictate this development and how local decision-makers, with their own political interests, are attempting to refuse or resist the conservation vision. As such, the case of the potential Făgăraș Mountains National Park presents an emerging conflict between different actors attempting to materialize their own visions for the landscape. In between the two chief narratives employed by two of the main actors conservationists and local decision-makers - are the divergent narratives around conservation that local community members employ. The array of diverse positions towards the conservation initiative reflect the heterogeneity of local community members and how they may experience the detriments and benefits of the initiative differently (Horowitz 2011, 2010). The socio-economic context of many of the villages surrounding the Făgăraș Mountains emphasize the need for local economic development, which is a concern among local community members as well preserving local way of life, especially livelihoods and land use. Both conservationists' and the local decision-makers' visions resonate, in different ways, with the local livelihood needs and practices.

Political ecology provides a useful framework for untangling these conservation narratives as it directs attention to the political economy, history, and socio-economic contexts of the issues under scrutiny (Robbins 2012). The narratives around deforestation have strong roots in the history of land-use and the rapid change in the political landscape that Romania went through following the huge changes of 1989. In the wake of the Romanian Revolution, deforestation became an increasingly prominent issue in the Făgăraş Mountains and this development has influenced local narratives not only regarding deforestation, but also conservation as a whole. This is a function of the rapid and drastic changes that characterize the shift from communism to capitalism, especially the changes in property rights and the privatization of land with the land reforms in the 1990s and 2000s (land law 18/1991, 1/2000, and 247/2005). This complex historical context is crucial in understanding the conservation narratives of contemporary national park establishment. These changes in societal structures also shape the chief narrative among conservationists, since their vision is based on un-doing what has been done (deforestation as a result of land restitution) and returning the Făgăraș Mountains to their "original" state as wilderness.

\section{Bibliography}

Adams, W.M. 2017. Sleeping with the enemy? Biodiversity conservation, corporations and the green economy. Journal of Political Ecology 24: 243-257.

Ambinakudige, S. 2011. National Parks, coffee and NTFPs: the livelihood capabilities of Adivasis in Kodagu, India. Journal of Political Ecology 18: 1-10. 
Andonova, L. 2005. The Europeanization of environmental policy in Central and Eastern Europe. In F. Schimmelfenning and U. Sedelmeier (eds.). The Europeanization of Central and Eastern Europe. New York: Cornell University Press. Pp. 135-155.

Bauer, N., M. Vasile and M. Mondini. 2018. Attitudes towards nature, wilderness and protected areas: a way to sustainable stewardship in the South-Western Carpathians. Journal of Environmental Planning and Management 61(5-6): 857-877.

Bixler, R.P. 2013. The political ecology of local environmental narratives: power, knowledge, and mountain caribou conservation. Journal of Political Ecology 20(1): 273-285.

Blavascunas, E. 2014. When foresters reterritorialize the periphery: Post-socialist forest politics in Białowieża, Poland. Journal of Political Ecology 21(1): 475-492.

Bouriaud, L. 2005. Causes of illegal logging in Central and Eastern Europe. Small-Scale Forest Economics, Management and Policy 4(3): 269-291.

Bouriaud, L. and M. Marzano. 2015. Conservation, extraction and corruption: Is sustainable forest management possible in Romania? In E. Gilberthorpe and G. Hilson (eds.). Natural resource extraction and indigenous livelihoods: development challenges in an era of globalization. Farnham: Ashgate. Pp. 221240.

Bratman, G.N., J.P. Hamilton and G.C. Daily. 2012. The impacts of nature experience on human cognitive function and mental health. Annals of the New York Academy of Sciences 1249(1): 118-136.

Braun, V. and V. Clarke. 2006. Using thematic analysis in psychology. Qualitative Research in Psychology 3(2): 77-101.

Bridge, G., J. McCarthy and T. Perreault. 2015. Editors' introduction. In G. Bridge, J. McCarthy, and T. Perreault (eds.). The Routledge handbook of political ecology. New York: Routledge. Pp. 3-18.

Brockington, D. 2004. Community conservation, inequality and injustice: myths of power in protected area management. Conservation and Society 2(2): 411-428.

Brown, J.C. and M. Purcell. 2005. There's nothing inherent about scale: political ecology, the local trap, and the politics of development in the Brazilian Amazon. Geoforum 36: 607-624.

Buckley, R. 2011. Tourism and environment. Annual Review of Environment and Resources 36(1): 397-416.

Büscher, B. 2012. Inverted commons: Africa's nature in the global imagination. In D. Münster, U. Münster and S. Dorondel (eds.) Fields and forests: ethnographic perspectives on environmental globalization. Munich: Rachel Carson Centre. Pp. 31-37.

Byrne, J. and J. Wolch 2009. Nature, race, and parks: past research and future directions for geographic research. Progress in Human Geography 33(6): 743-765.

Campbell, L.M. 2007. Local conservation practice and global discourse: a political ecology of sea turtle conservation. Annals of the Association of American Geographers 97(2): 313-334.

Cortés-Vázquez, J. 2014. A natural life: neo-rurals and the power of everyday practices in protected areas. Journal of Political Ecology 21: 493-515.

Cotoi, C. 2017. The making of a national park: ruins of nature and history in Northern Dobrudja. East European Politics and Societies 31(3): 596-614.

Cundill, G., J.C. Bezerra, A. De Vos and N. Ntingana. 2017. Beyond benefit sharing: place attachment and the importance of access to protected areas for surrounding communities. Ecosystem Services 28: 140-148.

Dorondel, S. 2007. Ethnicity, state, and access to natural resources in Southeast Europe: the Rudari case. In S. Serban (ed.). Transborder identities: the Romanian-speaking population in Bulgaria. Bucharest: Paideia. Pp. 215-240.

Dorondel, S. 2016. Disrupted landscapes: state, peasants, and the politics of land in post socialist Romania. New York: Berghahn Books.

Elmhirst, R. 2011. Migrant pathways to resource access in Lampung's political forest: gender, citizenship and creative conjugality. Geoforum 42(2): 173-183. 
European Environment Agency. 2012. Protected areas in Europe - an overview. Copenhagen: EEA. [accessed July 11 2018].

Fletcher, R. 2010. Neoliberal environmentality: towards a poststructuralist political ecology of the conservation debate. Conservation and Society 8(3): 171-181.

Haenn, N., E. Olson, J. Martinez-Reyes and L. Durand. 2014. Introduction: between capitalism, the state, and the grassroots: Mexico's contribution to a global conservation debate. Conservation and Society 12(2): 111-119.

Hansson, S. and F. Trabelsi. 2017. "Romerna är romer och vi är rudari" En kvalitativ studie om kvinnliga EUmigranters identitetsuppfattningar. Thesis. Sweden: Jönköping University.

Hitchins, K. 2014. A concise history of Romania. Cambridge: Cambridge University Press.

Hoffman, A. 2009. Shades of green. Stanford, CA: Stanford Social Innovation Review.

Holmes, G. and C. Cavanagh 2016. A review of the social impacts of neoliberal conservation: formations, inequalities, contestations. Geoforum 75: 199-209.

Horowitz, L. 2010 "Twenty years is yesterday": science, multinational mining, and the political ecology of trust in New Caledonia. Geoforum 41(4): 617-626.

Horowitz, L. 2011. Interpreting industry's impacts: micropolitical ecologies of divergent community responses. Development and Change 42(6): 1379-1391.

Igoe, J. and D. Brockington. 2007. Neoliberal conservation: a brief introduction. Conservation and Society 5(4): $432-449$.

Ilie, L. 2019. Thousands of Romanians protest against illegal logging, attacks on forest workers. Reuters 3 November [accessed November 20 2019].

Iojă, C. I., M. Pâtroescu, L. Rozylowicz, V.D. Popescu, M. Vergheleț, M.I. Zotta and M. Felciuc. 2010. The efficacy of Romania's protected areas network in conserving biodiversity. Biological Conservation 143(11): 2468-2476.

Iorio, M. and M. Corsale. 2010. Rural tourism and livelihood strategies in Romania. Journal of Rural Studies 26(2): 152-162.

Jacoby, K. 2001. Crimes against nature: squatters, poachers, thieves and the hidden history of American conservation. Berkeley: University of California Press.

Jones, N., J. McGinlay and P. Dimitrakopoulos. 2017. Improving social impact assessment of protected areas: a review of the literature and directions for future research. Environmental Impact Assessment Review 64: $1-7$.

Kathmann, F., A. Ciutea, I.-A. Biris, P.L. Ibisch and V. Sălăgeanu. 2017. Potential primary forests map of Romania. Bucharest.: Greenpeace. [accessed May 30 2019].

Kay, K. 2014. Europeanization through biodiversity conservation: Croatia's bid for EU accession and the Natura 2000 designation process. Geoforum 54: 80-90.

Kelly, A. 2011. Conservation practice as primitive accumulation. Journal of Peasant Studies 38(4): 683-701.

Keulartz, J. 2009. European nature conservation and restoration policy - Problems and perspectives. Restoration Ecology 17(4): 446-450.

King, B. 2010. Conservation geographies in Sub-Saharan Africa: the politics of national parks, community conservation and peace parks. Geography Compass 4(1): 14-27.

Kiss, A. 2004. Is community-based ecotourism a good use of biodiversity conservation funds? Trends in Ecology and Evolution 19(5): 232-237.

Langholz, J. and J. Lassoie. 2001. Perils and promise of privately owned protected areas. BioScience 51(12): 1079-1085.

Măntescu, L. and M. Vasile. 2009. Property reforms in rural Romania and community-based forests. Sociologie Românească VII(2): 95-113.

McGrath, S. 2019. Romania forest murder as battle over logging turns violent. BBC News 21 October [accessed November 1 2019]. 
Ministerul Apelor și Pădurilor. 2019. Catalogul național al pădurilor virgine şi cvasivirgine din România. Bucharest: Ministerul Apelor și Pădurilor. [accessed May 30 2019].

Mombeshora, S. and S. Le Bel. 2009. Parks-people conflicts: the case of Gonarezhou National Park and the Chitsa community in South-East Zimbabwe. Biodiversity and Conservation 18(10): 2601-2623.

Neumann, R.P. 2015. Nature conservation. In T. Perreault, G. Bridge and J. McCarthy (eds.). The Routledge handbook of political ecology. New York: Routledge. Pp. 391-405.

Neumann, R.P. 2001. Disciplining peasants in Tanzania: from state violence to self-surveillance in wildlife conservation. In N. Peluso and M.J. Watts (eds.). Violent environments. Ithaca, NY: Cornell University Press. Pp. 305-327

Neumann, R.P. 2009. Political ecology: theorizing scale. Progress in Human Geography 33(3): 398-406.

Overton, J. 1996. Making a world of difference: essays on tourism, culture and development in Newfoundland. St. John's, Newfoundland: Institute of Social and Economic Research.

Petrova, S. 2014. Contesting forest neoliberalization: recombinant geographies of "illegal" logging in the Balkans. Geoforum 55: 13-21.

Pietrzyk-Kaszyńska, A., J. Cent, M. Grodzińska-Jurczak and M. Szymańska. 2012. Factors influencing perception of protected areas: the case of Natura 2000 in Polish Carpathian communities. Journal for Nature Conservation 20(5): 284-292.

Pretty, J. and D. Smith. 2004. Social capital in biodiversity conservation and management. Conservation Biology 18(3): 631-638.

Pullin, A., M. Bangpan, S. Dalrymple, K. Dickson, N. Haddaway, J. Healey, H. Hauari, N. Hockley, J.P.G. Jones, T. Knight, C. Vigurs, and S. Oliver. 2013. Human well-being impacts of terrestrial protected areas. Environmental Evidence 2(19): 1-41.

Radel, C. 2012. Gendered livelihoods and the politics of socio-environmental identity: women's participation in conservation projects in Calakmul, Mexico. Gender, Place and Culture 19(1): 61-82.

Robbins, P. 2012. Political ecology: a critical introduction. Chichester: Wiley-Blackwell.

Roth, R. 2004. On the colonial margins and in the global hotspot: people-park conflicts in highland Thailand. Asia Pacific Viewpoint 45(1): 1-32.

Salafsky, N. and E. Wollenberg. 2000. Linking livelihoods and conservation: a conceptual framework and scale for assessing the integration of human needs and biodiversity. World Development 28(8): 1421-1438.

Sen, A. and S. Pattanaik. 2017. How can traditional livelihoods find a place in contemporary conservation politics debates in India? Understanding community perspectives in Sundarban, West Bengal. Journal of Political Ecology 24: 861-880.

Sodhi, N., T.M. Lee, C. Sekercioglu, E. Webb, D. Prawiradilaga, D. Lohman, N.E. Pierce, A.C. Diesmos, C. Arvin, R. Madhu and P. Ehrlich. 2010. Local people value environmental services provided by forested parks. Biodiversity and Conservation 19(4): 1175-1188.

Sodikoff, G. 2009. The low-wage conservationist: biodiversity and perversities of value in Madagascar. American Anthropologist 111(4): 443-455.

Staddon, C. 2009. Towards a critical political ecology of human-forest interactions: collecting herbs and mushrooms in a Bulgarian locality. Transactions of the Institute of British Geographers 34(2): 161-176.

Stahl, J. 2010. Rent from the land: a political ecology of postsocialist rural transformation. London: Anthem Press.

Vaccaro, I., O. Beltran and P.A. Paquet. 2013. Political ecology and conservation policies: some theoretical genealogies. Journal of Political Ecology 20: 255-272.

Vasile, M. 2008. Nature conservation, conflict and discourses on forest management: communities and protected areas in Meridional Carpathians. Sociologie Românească, (3-4): 87-100.

Walentowski, H., E.D. Schulze, M. Teodosiu, O. Bouriaud, A. von Heßberg, H. Bußler L. Baldauf, I. Schulze, J. Wäldchen, R. Böcker, S. Herzog, and W. Schulze. 2013. Sustainable forest management of Natura 2000 sites: a case study from a private forest in the Romanian Southern Carpathians. Annals of Forest Research 56(1): 217-245. 
Walker, P. and L. Fortmann. 2003. Whose landscape? A political ecology of the "exurban" Sierra. Cultural Geographies 10(4): 469-491.

West, P., J. Igoe and D. Brockington. 2006. Parks and peoples: the social impact of protected areas. Annual Review of Anthropology 35(1): 251-277.

Yakusheva, N. 2017. Parks, policies and people: nature conservation governance in post-socialist EU countries. Ph.D. dissertation. Sweden: Södertörns Högskola. 